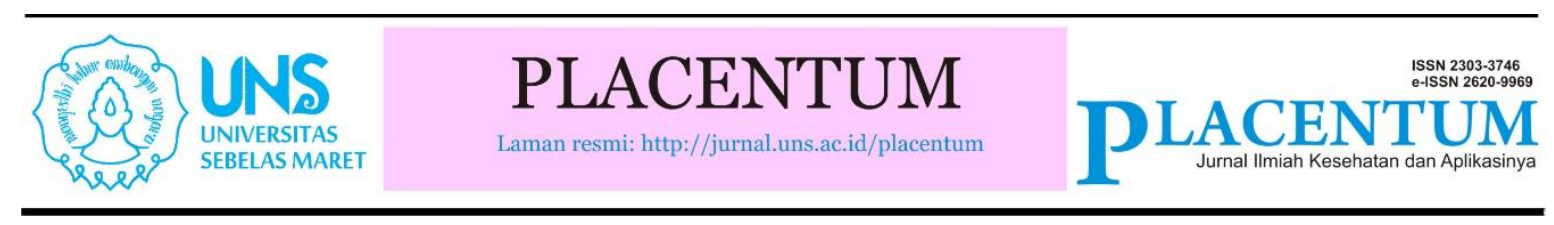

\title{
Knowledge and Anxiety in Midwives in the COVID-19 Pandemic
}

\author{
Nurul Sya'bin ${ }^{*}$ \\ ${ }^{1}$ Prodi Sarjana Kebidanan dan Pendidikan Profesi Bidan Universitas Medika Suherman, \\ Jl. Raya Industri Pasir Gombong Jababeka, Cikarang - Bekasi 17530 telp. (021) 89111110 \\ * Corresponding author \\ E-mail: nurul@medikasuherman.ac.id
}

\begin{abstract}
The incidence of COVID-19 cases continues to increase day by day so that health workers as the front line are increasingly under pressure due to the increasing workload, worrying about their health, and their families ${ }^{[1]}$. One thing that can cause health workers to experience increased anxiety, one of which is the lack of Personal Protective Equipment (PPE) in the workplace ${ }^{[2]}$. Health workers are at risk of experiencing psychological disorders in treating Covid-19 patients due to feelings of depression, the main cause of which is selfprotection which is still less than the needs of health workers ${ }^{[3]}$. The purpose of this study was to determine the relationship between knowledge and anxiety in midwives in the COVID-19 pandemic at the Bekasi District Hospital. This study used cross sectional design. The population of all midwives in the Bekasi Regency General Hospital was 48 people. The sampling used was sampling technique by stating several criteria. If it does not meet the inclusion criteria, it is not used. Data analysis using chi square and logistic regression. The results of the statistical test of the knowledge factor with anxiety in midwives during the COVID-19 pandemic using chi square got a value of sig $=0.01$. The conclusion of this research is that knowledge has a significant relationship with anxiety in midwives during the COVID19 pandemic at the Bekasi District Hospital in 2021.
\end{abstract}

Keywords: knowledge, anxiety, midwifery

\section{INTRODUCTION}

The incidence of Covid-19 cases continues to increase from day to day so that health workers as the front line are increasingly under pressure due to the increasing workload, worrying about their health, and their families ${ }^{[1]}$. One thing that can cause health workers to experience increased anxiety, one of which is the lack of Personal Protective Equipment (PPE) in the workplace ${ }^{[2]}$. Health workers are at risk of experiencing psychological disorders in treating Covid-19 patients due to feelings of depression, the main cause of which is selfprotection which is still less than the needs of health workers ${ }^{[3]}$.

According to the World Health Organization (WHO) on April 6, 2020, the number of sufferers in the world was 1,278,523 infected with Covid-19 cases. Of the 1.2 million positive cases of corona, 69,757 (5.46\%) Covid-19 patients have died and 266,732 (20.9\%) have recovered from the total positive cases. Meanwhile in 
Indonesia, the latest data on the number of positive cases of the corona virus (Covid-19) still shows an increase of 2,491 cases. The death rate of Covid-19 patients also continued to increase by 209 people $(8.39 \%)$ and 192 people $(7.70 \%)$ recovered from the number of positive patients. From the comparison of these data, Indonesia is still experiencing an increase in the number of deaths and patient recovery rates ${ }^{[4]}$.

According to data from the Crisis Center of the Ministry of Health (2020), the highest number of sufferers or cases in DKI Jakarta Province is 1,232 positive. cases, with 99 deaths and 65 people recovered, West Java Province in second place with 263 positive cases, 29 died and 13 recovered, and East Java in third place with 189 positive cases, 14 died and 38 recovered. While South Sulawesi Province occupies the sixth position with 113 positive cases, 6 died and 19 recovered $^{[6]}$.

One of the survey results in the United States was obtained from February 12 to April 9, 2020, it was found that 9,282 (19\% of 49,370) health workers were infected with the corona virus. Spain reports infections in healthcare workers at $20 \%$. In Malaysia, the government has reported that $5.8 \%$ of positive cases were health workers. In Indonesia, there is no definite data regarding confirmed positive health workers, but it is estimated that by May 6 , there are 721 to 2,488 health workers who have been infected and 20 people have died [6].

Health workers, especially doctors, nurses, midwives are currently part of the professional community that has an impact on the condition of this pandemic. Nurses and Midwives are currently one of the health workers who are at the forefront of the current COVID-19 response. The impacts that occur on nurses and midwives are physical impacts such as fatigue, the risk of transmission, and suffering from COVID19. Many infected people, including health workers, show minimal or no symptoms when infectious, for example early in the course of infection ${ }^{[7]}$. Research stated that health workers are vulnerable and at high risk of being infected with severe acute respiratory diseases such as SARS. Health workers are vulnerable and at high risk of infection.

The availability of personal protective equipment for health workers is still lacking, so many health workers have been exposed to the virus and some have even died ${ }^{[2]}$. The psychological response experienced by health workers to infectious disease pandemics is increasing because it is caused by feelings of anxiety about one's own health and the spread of the family ${ }^{[1]}$. Anxiety is a worry that is not clearly felt by someone with feelings of uncertainty and helplessness ${ }^{[9]}$. Panic and fear are part of the emotional aspect, while the mental or cognitive aspects are the emergence of disturbances in attention, worry, irregularity in thinking, and feeling confused ${ }^{[10]}$. So that due to the Covid-19 incident, health workers feel pressured and worried.

The risk of psychosocial problems also occurs in health workers. Some of these risks are emotional exhaustion, posttraumatic stress. The number of people who suffer mental health effects after a major Event is often greater than the number of people who are seriously injured, and the mental health effects may last longer. Mental health is much more attractive to planning personnel and resources ${ }^{[7]}$. This is also reinforced by ${ }^{[3]}$ which states that health workers who are exposed to the coronavirus disease 2019 (COVID-19) can experience psychological stress. The same result was also stated by ${ }^{[8]}$ who stated in the results of his research that the health workers who were at high risk of contracting SARS appeared to have not only chronic stress but also higher levels of depression and anxiety. Therefore, it demands that health workers need preparation as stress management.

Cheng research et al's stated that out of 13 participants experienced anxiety because protective supplies had not been met when taking action to patients ${ }^{[1]}$. Health workers are a group that is very vulnerable to being infected with COVID-19 because they are at 
the forefront of handling cases, therefore they must be provided with complete PPE according to the WHO protocol so that the anxiety experienced is reduced ${ }^{[8]}$. According to ${ }^{[11]}$ health workers feel anxious because of high workload demands, including increasing working time, increasingly difficult to get social support, community stigma against health workers, personal protective equipment that limits movement, lack of information about long-term exposure to infected patients, and fear of health workers will transmit Covid-19 to friends and family because of the field of work.

The purpose of this study was to determine the relationship between knowledge and anxiety in midwives in the COVID-19 pandemic at the Bekasi District Hospital.

\section{METHOD}

This study used a cross sectional study design. The research was conducted at the Bekasi District Hospital. The type of research conducted is an analytical survey. The population in this study were all midwives who served in the Bekasi District Hospital. The sample was conducted using purposive sampling, by stating several criteria. The number of samples in this study was 45 people. The independent variable in this study is knowledge, and the dependent variable is anxiety during the COVID-19 pandemic. The instrument in this study used Generalized Anxiety Disorder-7 to measure the anxiety of midwives. Data analysis consisted of univariate, bivariate and multivariate analysis. Univariate analysis was used to determine the frequency distribution of each variable. Bivariate analysis was used to determine the relationship between knowledge and anxiety in midwives during the COVID-19 pandemic using the test chi-square. The relationship between variables is said to be meaningful if the $p$-value $<0.05$.

\begin{tabular}{|c|c|c|}
\hline \multicolumn{3}{|c|}{ RESULT } \\
\hline \multicolumn{3}{|c|}{ Univariate Analysis } \\
\hline \multicolumn{3}{|c|}{$\begin{array}{l}\text { Table 1. Frequency Distribution Based } \\
\text { on anxiety Midwives during the COVID-19 } \\
\text { Pandemic at Bekasi District Hospital } 2021\end{array}$} \\
\hline Anxiety & Frequency & $\begin{array}{c}\text { Percentage } \\
(\%)\end{array}$ \\
\hline No Anxiety & 24 & $47 \%$ \\
\hline Anxiety & 21 & $43 \%$ \\
\hline Total & 45 & $100 \%$ \\
\hline
\end{tabular}

Based on table 1, it can be seen that most of the respondents did not experience anxiety during the covid-19 pandemic, namely 45 respondents (47\%) while respondents who experienced anxiety were 21 respondents $(43 \%)$.

Table 2. Frequency Distribution Based on Knowledge of Midwives about Covid-19 at Bekasi District Hospital 2021

Knowledge Frequency Percentage

\begin{tabular}{ccc} 
& & $(\%)$ \\
\hline Good & 34 & $76 \%$ \\
Less & 11 & $24 \%$ \\
Total & 45 & $100 \%$ \\
\hline
\end{tabular}

Based on table 2, it can be seen that most of the respondents have good knowledge about covid-19, namely 34 respondents $(76 \%)$ while respondents who have less knowledge are 11 respondents $(24 \%)$.

\section{Bivariate Analysis}

Table 3 Relationship between Knowledge and Anxiety in Midwives during the Covid-19 Pandemic at the Bekasi District Hospital in 2021

\begin{tabular}{|c|c|c|c|c|c|c|c|}
\hline \multirow[t]{4}{*}{ Knowledge } & \multicolumn{4}{|c|}{ Anxiety } & \multirow[t]{4}{*}{$\mathbf{N}$} & \multirow[t]{4}{*}{$p$} & \multirow[t]{4}{*}{ OR } \\
\hline & \multirow{2}{*}{\multicolumn{2}{|c|}{$\begin{array}{c}\text { No } \\
\text { Anxiety }\end{array}$}} & \multirow{2}{*}{\multicolumn{2}{|c|}{ Anxiety }} & & & \\
\hline & & & & & & & \\
\hline & $\mathrm{n}$ & $\%$ & $\mathrm{n}$ & $\%$ & & & \\
\hline Good & 22 & 65 & 12 & 35 & 34 & 0,01 & 8,25 \\
\hline Less & 2 & 18 & 9 & 82 & 11 & & \\
\hline Total & & 24 & 53 & 21 & 47 & 45 & \\
\hline
\end{tabular}


Based on table 3 , it is known that respondents who experienced no anxiety during the COVID-19 pandemic were 24 respondents (53\%) with good knowledge of 22 respondents $(65 \%)$. Based on the results of the statistical test, chi square the $p$ value of 0.01 means that there is a relationship between the availability of PPE and the anxiety of midwives during the COVID-19 pandemic at the Bekasi District Hospital. An OR value of 8.25 means that mothers who have less knowledge will be at risk of 8.2 times greater anxiety during the COVID-19 pandemic than mothers who have good knowledge.

\section{DISCUSSION}

The results of this study are in line with research from Fadli, et al, which stated that there was a significant relationship between knowledge and anxiety in health workers in efforts to prevent Covid-19 ( $p$ value $0.03)^{[12]}$. The results of this study were also strengthened by the Ramadhan research which stated that there was a significant relationship between knowledge and anxiety of health workers in providing midwifery services during the Covid-19 pandemic ${ }^{[2]}$.

Knowledge is the result of knowing and this happens after people sense a certain object $^{[14]}$. Knowledge basically consists of a number of facts and theories that allow a person to be able to solve the problems he faces. This knowledge is obtained both from direct experience and through the experience of others. Factors that influence knowledge include: age, experience, education, occupation, gender, information, environment, socio-culture ${ }^{[15]}$.

Most of the midwives have good knowledge $(76 \%)$ on preventing virus transmission. But there are still many who experience anxiety (43\%). This could be due to higher job demands, including long working hours, the increasing number of patients and best practices that continue to change as information about Covid-19 develops ${ }^{[11]}$. Therefore, great support from the government is needed for the provision of personal protective equipment, training for health workers, as well as additional health benefits for both themselves and their families.

A person's knowledge is usually obtained from experience that comes from various sources such as poster media, close relatives, mass media, electronic media, manuals, health workers, and so on. Knowledge is a process by using the five senses that is done by a person on certain objects that can produce knowledge and the relationship of one's skills with anxiety in health workers ${ }^{\left[{ }^{13]}\right.}$. Knowledge is the result of what a person knows and this occurs after the person has sensed a particular object. Knowledge or cognitive is a very important dominant for the formation of one's actions, some human knowledge is obtained through the eyes and ears. In fact, behaviour based on knowledge will be more lasting than behaviour without knowledge ${ }^{[16]}$.

Anxiety or anxiety can be interpreted as unpleasant emotions including feelings of uncertainty, anxiety, fear, or worry that are felt objectively by midwives ${ }^{[17]}$. According to Phelan \& Ghostin, anxiety in health workers occurs due to a lack of understanding of the concept of preventing COVID-19 in the workplace, thereby reducing the ability to adapt to current conditions $^{[18]}$. Anxiety that occurs during this covid-19 pandemic, will have a negative influence on mental health and will affect performance in providing services ${ }^{[19]}$.

The very rapid spread of COVID-19 and the severity of symptoms it can cause in a segment of infected individuals has weighed heavily on the boundaries of the health care system. Maintaining adequate health personnel in this crisis requires not only a sufficient number of doctors, nurses, advanced practice physicians, pharmacists, respiratory therapists, but also maximize the mental health of each doctor to treat patients. Given that the spike in critically ill patients can last weeks to months, it is also important that healthcare professionals are able to work to their full potential over extended time intervals. At the same time that they are 
coping with the changing social and emotional stressors faced by everyone, health care professionals face greater exposure risks, extreme workloads, morale, dilemmas, and a rapidly evolving practice environment that is very different from what they were used to know ${ }^{[19]}$.

\section{CONCLUSION}

The conclusion of this research is that knowledge has a significant relationship with anxiety in midwives during the COVID-19 pandemic at the Bekasi District Hospital in 2021.

The limitation of this research is this research only conducted in one place, so the sample size in this study is small. This research was only carried out on midwives so they could not fully understand the anxiety related to health workers during the COVID-19 pandemic.

Suggestions for future researchers are to expand the research area so that the sample size is larger and can be carried out on all health workers, not only midwives.

\section{ACKNOWLEDGMENTS}

The author would like to thank the chairman of the Medika Bahagia Foundation, Dr. Drg. Eddy Suharso, SH, M.Kes who has facilitated the cost of this research. We would like to express our gratitude to the midwives of the Bekasi District Hospital who have been willing to be respondents in this research, and to the Director of the Bekasi District Hospital who has allowed researchers to conduct the research.

\section{REFERENCE}

1. Cheng, Q., Liang, M., Li, Y., He, L., Guo, J., Fei, D., Zhang, Z. (2020). Correspondence Mental health care for medical staff in China during the COVID-19. Lancet. 7, 15-26. https:// doi.org/10.1016/S2215-0366(20)30078$\mathrm{X}$.

2. Ramadhan, A. (2020). Vitalnya ketersediaan APD untuk melindungi tenaga kesehatan. Jakarta. Retrieved from https://www.antaranews.com/ berita/1411158/vitalnya-ketersediaanapduntuk-melindungi-tenaga kesehatan.

3. Lai, J., Ma, S., Wang, Y., Cai, Z., Hu, J., Wei, N., Li, R. (2020). Factors Associated with Mental Health Outcomes Among Health Care Workers Exposed to Coronavirus Disease 2019. Journal American Medical Association, $3(3), 1-12$.

https://doi.org/10.1001/jamanetworkope $\underline{\text { n.2020.3976. }}$.

4. WHO. (2020a). Coronavirus disease 2019 (COVID-19) Situation Report -67.

5. WHO. (2020b). The World Health Organization declared the coronavirus outbreak a Global Public Health Emergency. Retrieved from https://www.worldometers.info/coronavi rus/.

6. Kemenkes., RI. (2020). Perkembagan Kasus Covid-19 Kumulatif Di Indonesia. Retrieved from http://pusatkrisis.kemkes.go.id/.

7. Kang L, Li Y, Hu S, et al. The mental health of medical workers in Wuhan, China dealing with the 2019 novel coronavirus. Lancet Psychiatry 2020; published online Feb 5. https://doi.org/10.1016/S22150366(20)30047-X.

8. Chong, M.Y., Wang, W.C., Hsieh, W.C., Lee, C.Y., Chiu, N.M., Yeh, W.C., Huang, O.L., Wen, J.K., Chen, C.L. 2004. Psychological Impact of Severe Acute Respiratory Syndrome on Health Workers in a Tertiary Hospital. British Journal of Psychiatry. 185, 127-133.

9. Stuart, G.W. 2016. Keperawatan Kesehatan Jiwa : Indonesia: Elsever. 
10. Ghufron, M. N., \& Risnawita, R. (2014). Teori-Teori Psikologi. Jogjakarta: ArRuzz Media.

11. IASC. (2020). Catatan tentang aspek kesehatan jiwa dan psikososial wabah Covid-19 (pp. 1-20).

12. Fadli, F., Safrudin, S., Ahmad, A.S., Sumbara, S., Baharuddin, R. 2020. Faktor yang Mempengaruhi Kecemasan pada Tenaga Kesehatan dalam Upaya Pencegahan COVID-19. Jurnal Pendidikan Keperawatan Indonesia. Vol. 6, No 1 (2020). https://doi.org/10.17509/jpki.v6i1.24546

13. Hidayat, A. 2008. Metode Penelitian Keperawatan dan Teknik Analisa Data Edisi pertama. Jakarta: Salemba Medika.

14. A. Wawan., Dewi, M. (2012). Teori Dan Pengukuran Pengetahuan Sikap Dan Perilaku Manusia. Yogyakarta: Nuha Medika

15. Nursalam. (2016). Metodologi Penelitian Ilmu Keperawatan Pendekatan Praktis Edisi 4. Jakarta : Salemba Medika.

16. Notoatmodjo, S. (2007). Promosi Kesehatan dan Ilmu Perilaku. Jakarta: Rineka Cipta.

17. Jeyanthi, I., Kavitha, R., 2008. Anxiety and Stress Among The Primigravida and The Multigravida. Department of Social Work, Cauvery College for Women, Trichy, 1.(2):128.

18. Phelan, A.L., Katz, R., Goztin, L.O. (2020). The Novel Coronavirus Origunating in Wuhan, China. Journal American Medical Association. DOI: 10.1001/jama.2020.1097

19. Shanavelt, T., Ripp, J., Trockel, M. (2020). Understanding and Addressing Sources of Anxiety Among Health Care Professionals During the COVID-19
Pandemic. Journal American Medical Association. Volume 323, Number 21. 